\title{
ISLAM AND GOOD GOVERNANCE IN NIGERIA: A CRITICAL ANALYSIS
}

\author{
EMMANUEL A. OJEWUNMI \\ DOI: $10.31364 /$ SCIRJ/v8.i6.2020.P0620778 \\ http://dx.doi.org/10.31364/SCIRJ/v8.i6.2020.P0620778
}

Ph.D. Student Department of Politics and International Relations, Lead City University, Ibadan.

\begin{abstract}
This paper establishes that the religion of Islam is a source of ethics and morality and it should not be a political force. The paper also discusses various perspectives of different schools of thought in Islam to political participation. It further considers the role s that have been played so far in the governance of Nigeria by the proponents of Islam. In essence, this paper will attempt to investigat e the interrelationship between Islam and politics.
\end{abstract}

Based on this, the paper has adopted the use of descriptive designs in its methodology and the use of the theory of functionalism to pr ove the importance of the subject matter in the political dispensation of Nigeria. Finally, this paper intends to prove that the activities of extremists in Nigeria have posed a threat to the continued existence of Nigeria and her sustainable governance before giving recom mendations on the influence of Islam in Nigeria's polity.

Keywords: Islam, Political system, Religion, Governance, Democracy.

\section{Introduction}

Islam as a religion means total submission to the will of Allah. Allah is the word used for God in Islam. Then a Muslim is the one who has submitted to the will of God. To Muslims, unbelievers are all people who have not submitted themselves to the will of God. In ad dition, three important Scriptures make up the Holy Book of Islam. They are as follows: Al-Quran, Al-Hadith, and Sharia.

Historically, Islam was introduced first into the kingdom of Kanem-Borno around the $10^{\text {th }}$ century and to Hausaland around the $14^{\text {th }}$ ce ntury (Ibenwa, 2014). The religion of Islam spread to Western Nigeria especially after the Fulani Jihad of the early $19^{\text {th }}$ century. Mean while, Islam is generally believed to be both a religion and a culture. It caims total control over all aspects of life of its adherents, both as individuals and as a group (Iremeka, 2005). To buttress this fact, (Kaltner: undated) argues that Muslims believe religion is an esse ntial aspect of a person's identity that influences every part of one's life. Faith is not something someone draws upon in times of need or celebrates only on a particular day of the week. (Kalltner: undated), in a summary, is of the opinion that Islam is a total way of life $t$ hat affects how muslims think whether they are in the mosque, the home or marketplace. Every area of muslim existence comes under the authority of Islam. Consequently, there is no separation of religion and politics in Islam. 


\section{Islam's Perspective of Democratic Governance}

There exist several perspectives on the relationship of Islam and democracy among Islam political theorists, the general Muslim $\mathrm{p}$ ublic, and Western authors. Firstly some modern Islamic thinkers whose ideas were famous in the 1970s and 1980s rejected the n otion of democracy as a foreign idea incompatible with Islam as shown in the Wikipedia page, Islam and Democracy. Last edited, $27^{\text {th }}$ May, 2020) Others have argued that traditional Islamic notions such as "Shura” (consultation), "Maslaha” (public interest), and " $a d l$ " (justice) justify representative government institutions that are similar to Western democracy but reflect Islam rather th an Western liberal values. Islam and Democracy. (Wikipedia last edited, $27^{\text {th }}$ May, 2020). Still, others have advanced liberal dem ocratic models of Islamic politics based on pluralism and freedom of thought. (Muslih, Bowers, 2009). Some Muslim thinkers ha ve advocated secularist views of Islam. (Esposito,2011)

In addition, several different attitudes regarding democracy are also represented among the general Muslim public, with polls indi cating that the majority in the Muslim world desires a political model where democratic institutions and values can coexist with $\mathrm{t}$ he values and principles of Islam seeing no contradiction between the two. (Esposito \& Delong-Bas, 2018). In practice, the politic al history of the modern Muslim has often been marked by undemocratic practices in states of both secular and religious character as illustrated in a publication by the PEW Research Centre (2012). Analysts have suggested a number of reasons for this includin $\mathrm{g}$ the legacy of colonialism, oil-wealth, the Arab-Israeli conflict, authoritarian secularist rulers, "the mind-set of Islam" and Islami c fundamentalism. (Magagh, Dalia, 2017)

A Muslim democrat Ahmad Moussalli, a professor of Political Science at the American University of Beirut, argues that concepts in the Quran point towards some forms of democracy or at least point away from despotism. He believes that government by the people is not therefore necessarily incompatible with the rule of Islam, whilst it has also been argued that rule by a religious autho rity is not the same as rule by a representative of God. This viewpoint, however, is disputed by some traditional Muslims. Moussa lli argues that despotic Islamic governments have abused the concepts of the Quran for their despotic end: "For instance, "Shura" , a doctrine that demands the participation of society in running the affairs of its government, became, in reality, a doctrine that w as manipulated by political and religious elites to secure their economic, social and political interests at the expense of other segm ents of society as seen in Wikipedia "Islam and Democracy". (Last edited, $27^{\text {th }}$ May, 2020)

The Sunni Islam believes that deliberations of the Caliphates, most notably the Rashidun Caliphate, were not democratic in the m odern sense rather, decisions-making power lay with a council of notable and trusted companions of Mohammed and representati ves of different tribes "most of them selected or elected within the tribes" (Encyclopedia of Islam and the Muslim World (2004) 
Vol .1. P. 116-123) The Sunni Islam scholars argue that in the early Islamic Caliphate, the head of state, the Caliph, had a positio $\mathrm{n}$ based on the notion of a successor to Muhammad's political authority who, according to Sunnis was ideally elected by the peop le or their representatives (Encyclopedia of Islam and the Muslim World:2004) as was the case for election of Abu Bakr, Umar bi n Alkallab, Uthman and Ali as Rightly Guided Caliphs. After the Rashidun Caliphs, later Caliphates during the Islamic golden ag e had a much lesser degree of collective participation, but since "no one was superior to anyone else except based on piety and vir tues" in Islam, and following the example of Mohammed, later Islamic rulers held public consultations with the people in their aff airs. (Weeramantry, 1997)

Muslih and Bowers (2009) identify three major perspectives on democracy among prominent Muslim scholars who have sought $\mathrm{t}$ o develop modern, distinctly Islamic theories of socio-political organization conforming to Islamic values and law. They are: first , the rejectionist Islamic view that condemns imitation of foreign ideas but stresses the comprehensive implementation of Sharia. Second is the moderate Islamic view that stresses the concept of "Maslaha" (public interest) "adl" (justice) and Sharia. Islamic le aders are considered to uphold justice if they promote the public interest, as defined through Sharia. This view provides the basis for representative government institutions that are similar to Western democracy but reflect Islamic rather than Western liberal va lues. Third, the liberal Islamic view that emphasizes the role of reason in understanding religion. It stresses democratic principles based on pluralism and freedom of thought. Islamic liberals argue for the necessity of constant re-examination of religious unders tanding, which can only be done in a democratic context.

The notion of secularism has been given strong negative connotations because of its associations with foreign colonial dominatio $\mathrm{n}$ and the removal of religious values from the public sphere. Traditional Islamic theory distinguishes between matters of religion "din" and state "dawla", but insists that political authority and public life must be guided by religious values (John, 2014). Propon ents of Islamism (political Islam) reject secularist views that would limit Islam to a matter of personal belief and insist on the imp lementation of Islamic principles on legal and political spheres. (John, 2014).

Muhammad Asad, (1961) in his view, describes democracy as perfectly compatible with Islam. He argues that Islam makes it inc umbent upon Muslims to subordinate their decisions to the guidance of the divine law revealed in the Quran and exemplified by $\mathrm{t}$ he Prophet an obligation which imposes definite limits on the community right to legislate and denies to the "will of the people" $t$ hat attribute of sovereignty which forms an integral part of the Western concept of democracy. Meanwhile, Abul A'la Maududi ( 1960) conceived of an "Islamic state" that would eventually "rule the earth". He coined the term 'Theo-democracy'. He argues th at it was different from Theocracy as understood in the Christian west because it would be run by the entire Muslim community $r$ 
ather than a clerical class in the name of God. (Ulah, 2013) But Youssef M. Choueiri criticized Maududi's vision as an ideologica 1 state in which legislators do not legislate, citizens only vote to reaffirm the applicability of God's laws, women rarely venture ou tside their homes lest social discipline is disrupted, and non-Muslims are tolerated as foreign elements required to express their lo yalty employing paying a financial levy. (Choueiri, 2010) Generally, Muslims believe religion is an important aspect of a person' s identity that influences every part of one's life. Kaltner (undated) argues that faith is not something someone draws upon solely in terms of need or celebrates only on a particular day of the week. Islam is a total way of life that affects how Muslims think and behave regardless of whether they are in the Mosque, the home, or the market place. Every area of human existence comes under the authority of Islam. (Kaltner, Kendra, Micah, 2007) In Islam, religion is supposed to reform and influence the political arena. T here is no clear agreement on what the ideal Islamic state should look like, but it is consistently held that Muslim principles and v alues must be at its core. Finally, one of the most hotly debated topics today concerns the compatibility of Islam and democracy. ( Kaltner, Kendra, Micah, 2007) Democracy indeed remains an unrealized ideal within the Islamic world, but many observers; Mus lim and non-Muslim alike maintain that this is due to a variety of cultural, historical, and political factors rather than an inherent o pposition to democracy within the religion. Many argue that certain concepts central to Islam-like consultation, consensus and the use of independent reasoning can aid in the formation of a distinctly Islamic form of democracy. (Kaltner, Kendra, Micah, 2007).

\section{Islam and Good Governance in Nigeria}

Islam is an old religion, with millions subscribing to the faith. In many historical periods, Islam has served as a source of unifying forc e (as seen in the case of the Sokoto Caliphate in the $19^{\text {th }}$ century). Islam has also contributed in many ways to Nigeria's development, notably in providing the resources to organize politics and society, fostering community cohesion and creating an ideology of change. (Falola, 2009).

Governance by its definition is conceptualized as the processes and systems by which a government manages that resource of the soci ety to address socio-economic and political challenges in the polity. Kaufman (2005) likewise sees government as the traditions and institutions by which authority in a country is exercised for the common good. Ganiyu, (in Ayantayo, Dada, Labeodan , 2012) believes that governance is viewed as the exercise of economic, political, and administ rative authority to manage a country's affairs at all levels. It comprises mechanisms, processes, and institutions through which citizens and groups articulate their interests, exercise their legal rights, meet their obligations and mediate their differences.(Kaufman, 2005)

On this premise, we can conclude that governance is said to be good when it is free from abuse, greed, and corruption. When it embra ces the rule of law, transparency, and accountability in the administration and management of the country's affairs.(Bassey, 
Ozumba, ed 2012) Furthermore, good governance implies the process by which authority is exercised in the management of a country 's economic and social resources in the interest of the majority of the citizens.(Edemhanria, undated) It also reflects on the capacity of the government to design, formulate, and implement policies and discharge functions in line with the relevant laws that are applicable and for the benefit of the people.(Edemhanria, undated) Meanwhile, the entrenchment of practices of good governance in Nigeria is a catalyst for the consolidation of democracy and sustainable development. This will act as a driving force with the potential to directly advance processes and create links between the three tiers of government and plan constructively as a key component for democratic governance and nation-building. .(Edemhanria, undated). Thus, Nigeria under various military rules (and even under the present demo cratic government of President Muhammadu Buhari) characterized by excessive arbitrariness (especially by the subjugation of the jud iciary and repression of the media) was ranked the most corrupt country in the world in 1996 and 1997 and also in 2018 by Transpare ncy International, an international non-governmental organization committed to fighting bribery in International trade. (Adamolekan, ed, 2011). The most powerful form of challenge to Nigeria's nascent democracy since this present democratic governance which bega n on May 29, 1999, to date was political Islam, which in the words of Williams Zartman "promises the restoration of morality, authent icity and earthly success and the exclusion of corruption and error, backed by God's word as a guide and guarantee”. (Zartman, 1969)

The religion of Islam believes that for Nigeria to enjoy good governance, emphasis must be placed on the following qualities for those in political power:

- Good justice must be in place. Those in authority are expected to be fair and nonpartisan even to one's tribe, family, and religion. The bad governance begins by being partial in the exercising of justice to one's tribe, family, or religion. This becomes the root cause of injustice, partiality, favoritism, ineptitude, and nepotism.

- Islam preaches freedom of conscience. For good governance to exist in Nigeria, there is a great need for total freedom of conscience and fearless criticism of a leader who is a tyrant. That was the reason why Chief Gani Fawehinmi who was a Muslim was critical of the tyrant governments of Generals Sanni Abacha and Ibrahim Babangida who were also Muslim heads of state. The fact is when people are denied the right to criticize rulers fearlessly, the rulers tend to be more authoritative and exploitative.(Ganiyu, in Ayantayo, Dada, Labeodan , 2012) But in a real sense, it is only in a democratic good governance that freedom of conscience can be realized but not in an authoritarian regime. The Islamic clerics have been challenging the people in government to avoid prejudice against people of other tribes or caste. While they shower favour on their family members, tribes, or religion. They deprive those not belonging to the community of their just right. The fact is that what is injustice today will become violent in society on a later day. 
- The religion of Islam believes in the equal treatment of all human beings in society. Everyone is believed to enjoy the privileges of life to the full, and should not be denied by any person or group of people and government in Nigeria because only God can give privileges to people. Meanwhile, governance in Nigeria must respect the dignity of everyone in the Nigerian society to avoid chaos and breakdown of law and order in society. Thus for Nigerians to enjoy good and democratic governance, differences of tribes and family background should not matter and only one who is conscious of his duties should enjoy the highest treatment. (Ganiyu, in Ayantayo, Dada, Labeodan , 2012)

- There must be shared responsibility among the people. There should be no concentration of political power within one individual or group of people at the expense of others. The religion believes that Islam is a religion that emphasizes the unity of God, Prophethood of Muhammed, and then righteous living. Dr. Taha (undated) argues further that Islam also draws attention towards this and the worldly life, but it did not deprive humans of their rights nor did it become of man or child. It neither stripped him of his initiative to act. That God commanded the Prophet (PBOH) to consult the faithfuls in their affairs. If everything had to be decided in the heavens, there was no need to consult anyone.

- The religion of Islam in Nigeria has been emphasizing the care for the weaker sex and sections of society. The Quran is greatly concerned with the fate of weaker sections of society. In the pre-Islamic society in Makkah, the poor, orphans, and widows were totally neglected thus chapter 107 of the Quran condemns those who neglect these categories of people in society.(Ganiyu, in Ayantayo, Dada, Labeodan, 2012) Thus, for those who neglect these sections, even if they pray, it is an effort in futility and a mere show-off. The Quran maintains that the struggle between the powerful and the weak is eternal and that Allah is on the side of the weak. Allah intends according to verse 5 of Q.25 to make the weak leaders and inheritors of this earth. Thus any government which is based on favouring the powerful and arrogant section of any given society is bound to attract Allah's wrath for it is violating the limit "hudud" laid down by Allah.(Ganiyu, in Ayantayo, Dada, Labeodan, 2012)

\section{Sharia and Good Governance in Nigeria: How Compatible?}

Zakiya (2004) argues in his paper, "Islam and Politics" that Islam is a religion bringing the mission of liberation and salvation. It brou ght new morality for solid transformation because of its metaphysical and humanitarian character. It is a religion deriving from God a nd oriented towards humanity, giving importance to both transcendental and social dimensions (Lily,18 ${ }^{\text {th }}$ March, 2004) Zamfara State kick-started the adoption of the Sharia legal system in 1999 and subsequently implemented its full scale the following year. Many oth er States in the North-Niger, Sokoto, Bauchi, Kaduna followed suit (Awofeso, March, 2016) But the decision by some Northern State 
to implement Sharia legal system is however perceived with some anxiety and fear by non-Muslims who roundly interpreted this actio $\mathrm{n}$ to mean an attempt to gradually Islamise Nigeria (Awofeso, March, 2016). Even though the mere implementation of Sharia legal co de does not single-handedly on its own connote an Islamic State as we were made to understand, it is observed that certain principles of democracy run contrary to some practices of Sharia as said by El-Zak-Zaky in Tell magazine (March, 2004) Akinsanya supports thi s argument when he writes that "several issues come to fore with the introduction of Sharia law by some Northern state: federalism, se cularity, the supremacy of the constitution, the sanctity of human right and rule of law" (Akinsanya, 2003). Besides, Honourable Justi ce Bello, former Chief Justice to the Supreme Court and a devoted Muslim, acknowledges the fact of non-compatibility of the Sharia 1 egal system and the section 38(1) of the 1999 constitution because of the offence of "ridda" (change in religion) which attracts capital punishment (Bello, 2000). Masih and Ibn Salam also argue in support of this opinion. They believe that one major thing that makes th e Sharia irrelevant for the modern man and woman is that it does not allow for freedom of religion. It does not allow freedom of consc ience. You cannot believe what you want to believe. A Muslim under the Sharia constitution has no right to leave Islam if he finds it $r$ easonable or justifiable to do so. The legal punishment "hada" for leaving Islam is death (Abdal-Masih, Ibn, 2000). In essence, the intr oduction of Sharia will lead to discrimination, it is against freedom of religion and conscience. For example, the prescription of beards wearing by a former Zamfara State governor, Alhaji Ahmed Sani Yerima as a prerequisite for receipt of an award of a contract by the state, and for receiving support from state government can best be described as discriminatory and "impositional". This fact is confir med in a statement he made that goes as follows" I enjoin Zamfara youths to grow beards from today. I myself will start growing it.

Whoever wants a contract must grow beards. Those without beards will not be considered. Even if you want to marry and are looking for government assistance it will be given to you only if you have a beard “ (Tell, November $15^{\text {th }}, 1999$ ) That is why Adaramoye final ly submits that the adoption of Sharia law in some States is a violent invasion of all the individual citizens of these states and a cruel a ssault on the rule of law, democracy, and human rights (Adaramoye in Feldner, 2001), and this is a contradiction to the teaching of the Quran that is in favour of the rule of law, social justice, freedom of conscience, equal treatment of all human beings and shared respo nsibility. This Sharia imposition in some States in the northern part of the country is one of the strong effects of political Islam in Nige ria which worked against good and democratic governance in Nigeria.

\section{Islamic Militancy or Extremism and Good Governance in Nigeria}

This is another aspect that poses a problem for the sustenance of democratic governance in Nigeria. The major Islamic organizations $t$ hat have become treats to the good governance are Boko Haram and of recent Islamic Movement of Nigeria (IMN). The modus-opera ndi are direct shooting, bombing, kidnapping e $\mathrm{t} c$. Their mission is to impose Islamic political systems into the country and force ever 
yone to embrace Islam. Muslims who are against this are regarded as infidels or apostates. Meanwhile, many Western and Muslim sch olars of Islam have posited that suicide attacks are a clear violation of classical Islamic law and characterized such attacks against civi lians as murderous and sinful (Lewis, Buntzie, 2008). The two scholars argues that "the emergence of the now widespread terrorism practice of suicide bombing is a development of the 20th century. It has no antecedent in Islamic history and no justification in terms of Islamic law, theology, or tradition (Lewis, Buntzie, 2008). Islamic legal rules of armed warfare or military Jihad are covered in deta il in classical texts of Islamic jurisprudence which forbade the killing of women, children or non-combatants, and the destruction of cu ltivated or residential areas. (Muhammed, 1987) In addition, many respected Muslim scholars have provided scholastic refutations of suicide bombings condemning them as terrorism prohibited in Islam and leading their perpetrators to hell. (Muhammed, 2011)

Historically, Boko Haram began in 2009 when the jihadist group started an armed rebellion against the Nigerian government. The con flict takes place within the context of longstanding issues of religious violence between Nigeria's muslim and Christian communities, and the insurgents' ultimate aim is to establish an Islamic state in the region (Wikipedia.com, August 19 $\left.{ }^{\text {th }}, 2019\right)$. Boko Haram's initial uprising and its leader Mohammed Yusuf was killed by the Nigerian government. The movement consequently fractured into groups and started an insurgency, though rebel commander managed to achieve kingship status among the insurgents. After years of fighting, the insurgents became increasingly aggressive, and started to seize large areas in Northern Nigeria. The violence escalated dramatical ly in 2014, with 10,849 deaths, while Boko Haram drastically expanded its territories. At the same time, the insurgemncy spread to ne ighbouring Cameroon, Chad and Niger, thus becoming a major regional conflict(Wikipedia, August 19, 2019). Boko Haram is current ly regarded as the deadliest terrorist group in terms of ther number of people it has killed.

Islamic Movement of Nigeria (IMN) is an Islamic religious and political organization based in Zaria, Kaduna state in the Northern re gion of Nigeria. The founder and leader of the group is Sheikh Ibrahin El-Zakzaky, a Shia Muslim cleric. The movement began with a Shia Muslim activist that was so impressed with the 1979 Iranian Revolution that he wanted one at home (Wikipedia, August 19, 201 9). The movement's crisis with the Nigerian government started when in 2015, the Nigerian Army Chief and his entourage were attac ked by this group in Zaria which led to the killings of many people. Since then, the leader of this group, El-Zakzaky and his wife have been in detention first in Abuja and later transferred to Kaduna.

These two militant/religious extremist groups are generally agreed to be threats to the sustainable governance in Nigeria. They have b ecome National religious malaise to the Nigerians. On the $18^{\text {th }}$ of March, 2017 for example, at least six people were killed and 16 wou nded as four female sucide bombers blew themselves up on the outskirts of Masiduguri city (Washington Post, 2017). Similarl;y, ISW AP fighters attacked a military base in the Nigerian town of Metele on $18^{\text {th }}$ November, 2019 killing at least 118 soldiers while at least 
153 others were declared missing sfter the attack, the millitants also seized tanks, armoured vehicles, weapons, aqnd ammunition (Dai ly Trust, undated)

To save Nigeria's democracy, urgent steps would need to be taken because continuous existence of these terrorists pose a great danger to the continuous peaceful existence of the diverse people of Nigeria.

\section{Conclusion}

In Nigeria, there is a fierce struggle for political power by the proponents of Islam for selfish ends. Most importantly, both Islam and Christianity compete for space, converts, and political domination. A combination of factors has made religion a powerful factor in Ni gerian politics. First is the failure of political leadership. Successive military leaders failed to transform the country,thereby making re ligious organizations to seek for alternative leaders and leadership models. The stress has been on morality, accountability, and spiritu ality. To many, Muslims Gadaffi of Libya and Khomeini of Iran provided alternative models to emulate. Second, the failure of govern ance in Nigeria has been seen to be the failure of the state. To the Muslims, this failure means the limitation of secularism in taking ca re of the welfare of the people. Third, the economic depression which has led to a high level of unemployment has given room for the high level of criminality, insecurity, and crisis in Nigeria. In addition, political campaigns that have been tailoring on the paths of ethn icity and religion have allowed a stern competition between Christianity and Islam. This attempt has radicalized the Christians in Nige ria to contest all religious symbols and what is perceived as efforts to Islamize the country and to fear Islamic religious domination.

To address the situation, and to guarantee good governance in Nigeria without violence the government should endeavour to address $\mathrm{t}$ his issue of economic depression. There must be justice in leadership style. Finally, without transforming Nigeria's economy and polit ics to suit the interests of the majority of Nigerians, the country should expect Islam to be firmly welded on issues around poverty, pol itical competitions, and alternative imaginations of the nation state.(Falola, 2009).

\section{References}

1. "6 killed as teenage girls detonate explosives". Washington Post Archived from the original on $20^{\text {th }}$ March, 2017.

2. “Many Soldiers killed, dozens injured as insurgents invade base in Borno”. www.dailytrust.ng. Retrieved $20^{\text {th }}$ August, 2019.

3. Abdal-Masih and Ibn S. M.J. 2000 “The Sharia question in Nigeria”. Nigeria: JPC. Inc

4. Adamolekan, L. ed 2011 "Public Administration in Africa: Main Issues and Selected Country Studies”: Second Edition. Ibadan. Evans Brothers (Nig Publishers). 
5. Akinsanya A. 2003 "Sharia and the Muslims in Nigeria: A Critical Overview" in the Sharia Issue. Working papers for Dialogue. (A working paper at a meeting of 32 eminent Nigerians on how to douse tension generated by the introduction of Sharia in some points of Northern States in August 2000)

6. Asad M. "The Principles of State and Government in Islam

7. Awofeso, O. "Political Islam and Democracy in Nigeria: Compatibility or Incompatibility?" Global Journal of Arts, Humanities, and Social Sciences. March 2016. Published by the European Centre for Research Training and Development UK. (www.eajournals.org). Vol 4, No 3, PP 1-11.

8. Bassey, C. O. and Ozumba, G. O. ed 2012 “Political Science: An Introductory Reader”. Lagos: Concept Publications.

9. Bello M. 2000 “Sharia and the Constitution”. In the Sharia Issue Working papers for Dialogue. (A working paper at a meeting of 32 eminent Nigerians on how to douse tension generated by the introduction of Sharia in some points of Northern States in August 2000).

10. Boko Haram Insurgency: Wikipedia. Downloaded on Auigust 2019 at 8:55 am.

11. Choueiri, Y. M. 2010. "Islamic Fundamentalism: The story of Islamic Movements" (3" ed). London: Bloomsbury Continuum. P. 144 ISBN 978-0-8264-9801-4.

12. Edemhanria I, I (undated). “The People's Power in Promoting Good Governance Benin”. Africa Network for Environment and Economic Justice (ANEEJ).

13. El Zak-zaky “Nigeria and Sharia Law” in Tell Magazine, March 2000.

14. Encyclopedia of Islam and the Muslim World (2004) Vol .1. P. 116-123.

15. Esposito, J. L. (2011) "Rethinking Islam, and Secularism" (PDF). Association of Religion Data Archives. Pp 13-15. Retrieved April 20, 2019.

16. Esposito, J. L; Delong- Bas, N. J. 2018. Shariah: What everyone needs to know. Oxford University Press. P 145

17. Falola, T. 2009 “Islam and politics in Nigeria”. Retrieved 2019.

18. Feldner, Y 2001 “72 Black-Eyed Virgins; A Muslim Debate on the Rewards of Martyrs”. Middle East Media Research Institute. Retrieved 8 October 2015

19. Ganiyu, M. A. "Islam and governance in Nigeria" in Ayantayo J.K, Dada, O.A \& Labeodan H.A (ed) 2012: “Religion and Governance in Nigeria”. Religious Studies Series, Vol. 4. Ibadan, Department of Religious Studies. U.I ISBN. 978-978-923413-4. Pg. 357.

20. Ibenwa, C.N. "Religion and Nation Building: A Critical Analysis.”. Internationa Journal of African Society, Cultures and 
Traditions. Vol 1, No 2, P.3. September 2014.

21. Iremeka, U.F. (2005) “The Place of Religion in National Development" in Ibenwa, C.N. "Religion and Nation Building: A Critical Analysis. ”.

22. Islam and Democracy: Retrieved from //en.wikipedia.org/w/index.php?title=Islam and Democracy_\& ordid=904234173. Last edited on $30^{\text {th }}$ June 2019 at 21:08

23. Islamic Movement (Nigeria). Wikipedia. Downloaded 19 ${ }^{\text {th }}$ August 2019. 9:19 am.

24. John L. E. ed 2014 "Secularism" The Oxford Dictionary of Islam. Oxford University Press.

25. Kaltner, J. “Religion and Politics:Islam”. Explore Faith Organization file: .//IC;Users/USER/ Documents/Religion\%20 and 20 politics.

26. Kaltner, J. “What do Our Neighbours Believe?” in Religion and Politics Islam. Explorefaith.org.

27. Kaufmann, D. 2005 “Myths and Realities of Governance and Corruption” in Working papers and articles, World Bank Washington D.C. Pg. 4

28. Lewis, B. \& Buntzie E. C. “Islam: The Religion and the People”. Wharton School Publishing: 2008 p.53

29. Lily Z. M. "Islam and Politics." Paper presented at the International Seminar on "Islam and Universal Values: Islam's Contribution to the Construction of a Pluralistic World" convened by the Embassy of Switzerland in Jakarta, $18^{\mathrm{TH}}$ March 2004.

30. Magah R; Dalia M 2017. Majorities See Religion and Democracy as Compatible”. Gallup.

31. Maududi, S. A. 1960. "Political Theory of Islam" 1993 ed). Lahore Pakistan; Islamic Publications. P. 35 the power to rule over the earth has been promised to the whole community of believers. Italics Original

32. Mislih, M; Bowers, M 2009:” Democracy.” In John L. E. (ed). The Oxford Encyclopaedia of the Islamic World: Oxford University Press.

33. Mohammed H. “The Muslim Conduct of State” (Ashraf Printing Press, 1987); ISBN 1-56744-340-0. PP 205-208.

34. Most Muslims Want Democracy, Personal Freedoms, and Islam in Political Life. Pew Research Center. Retrieved July 10, 2012.

35. Muslim Scholars Fatwa condemns terrorism.

36. Taha H. al-kubra Vol 1 Uthman U. tr. By Abdul H. N. Ajmal press, Bombay (nd). P. 28-29.

37. Tell, November 15, 1999: P.18.

38. Ulah, H. K. (2013). “Vying for Allah's Vote: Understanding Islamic Parties, Political Violence, and Extremism in Pakistan”.

WwW.scirj.org

(c) 2020, Scientific Research Journal

http://dx.doi.org/10.31364/SCIRJ/v8.i6.2020.P0620XX

This publication is licensed under Creative Commons Attribution CC BY. 
Georgetown University Press. P 79 ISBN 978-1-62616-015-6.

39. Weeramantry, C. G. 1997. Justice without Frontiers: Furthering Human Rights. The Hague: Kluwer Law International. P.135. ISBN 90-411-0241-8.

40. Zartman, W (1969) "Some Contending Issues in Democracy" in Eckstein, H, and Apter, D (eds) “Comparative Politics, A Reader”, New York: The Free Press. 